\title{
Shakespeare's Troilus and Cressida: Visualising Expectations as a Matter of Taste
}

Johann Gregory

\section{(2) OpenEdition}

Journals

\section{Electronic version}

URL: http://journals.openedition.org/shakespeare/1705

DOI: 10.4000/shakespeare. 1705

ISSN: 2271-6424

\section{Publisher}

Société Française Shakespeare

\section{Printed version}

Date of publication: 3 March 2012

Number of pages: $47-66$

ISBN: 2-9521475-8-2

\section{Electronic reference}

Johann Gregory, "Shakespeare's Troilus and Cressida: Visualising Expectations as a Matter of Taste », Actes des congrès de la Société française Shakespeare [Online], 29 | 2012, Online since 03 March 2012, connection on 19 April 2019. URL : http://journals.openedition.org/shakespeare/1705; DOI : 10.4000/ shakespeare.1705 


\section{Shakespeare et les arts de la table}

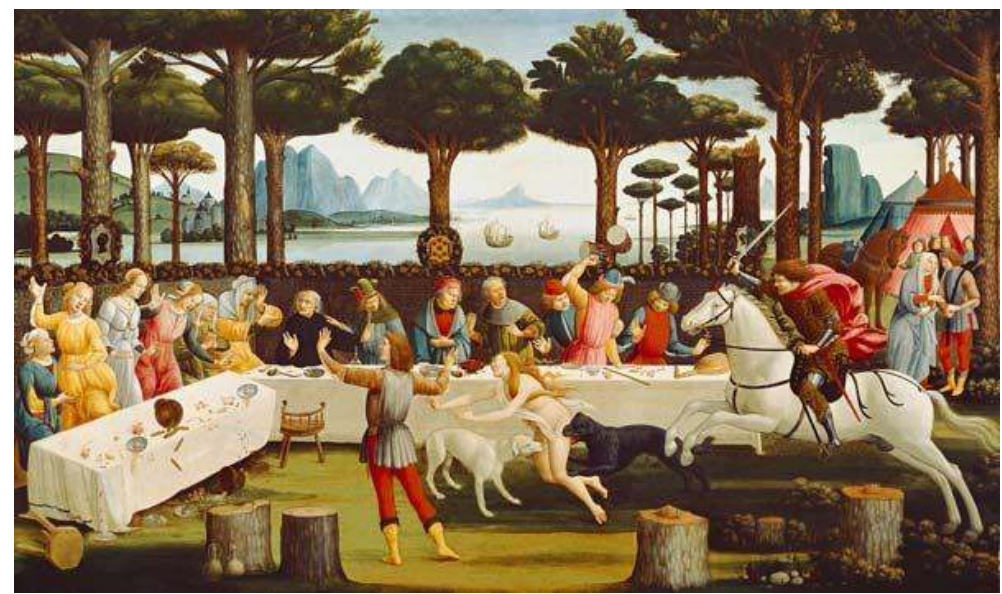

actes du Congrès

organisé par la

SOCIÉTÉ FRANÇAISE SHAKESPEARE

les 17, 18 et 19 mars 2011

textes réunis par

Christophe HAUSERMANN

et

Pierre KAPITANIAK

sous la direction de

Dominique GoY-BLANQUET 
COUVERTURE :

Botticelli, Banquet dans la forêt de pins,

Troisième tableau de la série

"L'histoire de Nastagio degli Onesti » inspiré d'une nouvelle du Décaméron de Boccace Musée du Prado, Madrid

conception graphique et logo

Pierre Kapitaniak

mise en page et corrections

Christophe Hausermann

Pierre Kapitaniak

(C) 2011 Société Française Shakespeare Institut du Monde Anglophone Université de Paris III - Sorbonne Nouvelle 5 rue de l'École de Médecine 75006 Paris

www.societefrancaiseshakespeare.org

Tous droits de traduction, de reproduction et d'adaptation réservés pour tous les pays 


\title{
SHAKESPEARE'S TROILUS AND CRESSIDA: Visualising Expectations as a MATTER OF TASTE
}

\author{
Johann GREGORY
}

W.R. Elton explains that Shakespeare's Troilus and Cressida has "been estimated [to contain] twice as many images of food, cooking and related matters as in any other of its author's works". This may seem surprising until we realise that the play utilises the language of food to create a poetics of expectation and taste. Although Thersites' performances are figured as a "cheese" to aid Achilles' "digestion" that should be "served in to [his] table", on the whole the drama is actually not consumed immediately by the audience. Rather, in a confusion of the senses, food becomes a visual metaphor for thinking an audience's appetite for a play and other matters of taste. The audience is invited to watch Troilus and Cressida as a monster that eats up, in its jaws, the notion of chivalry and "glorious deeds" that past versions of the story - in epic and romance - had been so keen to emphasise; it is these past traditions, the prologue promises, which "may be digested in a play". The paper seeks to discover whether the play leaves us with "fragments, scraps, the bits, and greasy relics" of past literature, or if Shakespeare was cooking up something else.

W. R. Elton explique que Troilus and Cressida comporte deux fois plus de références à la nourriture, à la cuisine et aux arts de la table que n'importe quelle autre pièce de Shakespeare. Cela peut sembler surprenant de prime abord, pourtant force est de constater que cette pièce utilise le vocabulaire de la nourriture pour créer une poétique de l'attente et du goût. Bien que le comportement de Thersite soit qualifié de « fromage » devant être " servi à la table d'Achille " pour favoriser sa " digestion », la pièce n'est pas consommée immédiatement par ses spectateurs. Dans une confusion des sens, la nourriture devient une métaphore visuelle représentant l'appétit dramatique des spectateurs ainsi que diverses affaires de goût. Ceux-ci sont invités à considérer Troilus and Cressida comme un monstre qui dévore entre ses mâchoires la notion de chevalerie et les faits d'armes que de plus anciennes versions de l'histoire - héritées des épopées et des romans courtois - ont cherché à valoriser. Le prologue nous promet que ces traditions du passé vont être " digérées dans la pièce ». Cette étude vise à découvrir si cette pièce accommode seulement les quelques « restes, fragments et reliques graisseuses » du passé, ou si Shakespeare avait à l'esprit de mijoter une tout autre chose.

"The tastebuds should be titillated, flirted with, provoked." The Debt to Pleasure ${ }^{1}$

\section{Hors d'œuvre: Healthy Reading}

7 ell me what kind of food you eat," says Jean Anthelme Brillat“ Savarin in The Physiology of Taste "and I will tell you what kind of a man you are".2 Brillat-Savarin's aphorism can

\footnotetext{
${ }^{1}$ John Lanchester, The Debt to Pleasure, London, Picador, 1996, p. 13. I am grateful to Professor Richard Wilson who provided food for thought in the early stages of this research, and to those at the Congrès 2011 de la Société Française Shakespeare for their questions and, especially, their "honest mirth and good company".

2 Jean Anthelme Brillat-Savarin, The Physiology of Taste; Or, Transcendental Gastronomy, trans. Fayette Robinson, Seaside, Oregon, Merchant Books, 2009, p. 14. This
} 
probably be seen as the nineteenth-century precursor to the $1960 \mathrm{~s}$ health food slogan, "you are what you eat". Confirmation that BrillatSavarin had read his Shakespeare may be taken from the fact that he finished his preface with a quotation from The Merchant of Venice. Brillat-Savarin closes his preface thus:

When I write of ME in the singular I gossip with my reader, he may examine, discuss, doubt or laugh; but when I say WE I am a professor, and all must bow to me.

"I am, Sir Oracle, And when I ope my lips, let no dog bark."

\section{The Merchant of Venice 3}

Demonstrating his good taste as a Shakespeare reader, Brillat-Savarin's rather Ozymandias-like expression, 4 nevertheless, seems to make a distinction between the pleasure or sociability of his topic on the one hand, and, on the other, the professional or scientific aspect of taste. The discourses surrounding matters of taste are also implicitly linked to the experience of reading as pleasure - the chance of "laugh[ter]" and as respect for professional knowledge, specifically respect for an author who is an authority on taste. This tie between eating and reading in their pleasure and science, however, is not simply an Enlightenment phenomenon; it can also be found, for a start, in early modern printed paratexts, and especially in texts concerned with health and matters of taste.

In an article for the journal Shakespeare, I sought to draw out the way in which the unique epistle to Troilus and Cressida sets up expectations for its readers by making promises about the play's elite status. ${ }^{5}$ However, to confer this status on Shakespeare's publication, the anonymous epistle writer acts as an authority on taste, taking the expression "a matter of taste" both metaphorically and literally. Positioning the reader literally as a consumer, the writer says "you have

was originally published in French as Physiologie du goût: ou Méditations de gastronomie transcendante in 1825 .

3 Brillat-Savarin, p. 26. Quotation from Shakespeare in English in the original French publication.

4 See Percy Bysshee Shelley's sonnet "Ozymandias": "And on the pedestal these words appear: / 'My name is Ozymandias, King of Kings: / Look on my Works, ye Mighty, and despair!"” in The Major Works, Oxford, Oxford University Press, 2009, p. 198.

5 See Johann Gregory, "Shakespeare's 'sugred Sonnets', Troilus and Cressida and the Odcombian Banquet: An exploration of promising paratexts, expectations and matters of taste ", Shakespeare 6, $\mathrm{n}^{\circ}$ 2, 2010, p. 185-208. 
here a new play, never staled by the stage". 6 The preface states that "this author's comedies" ( $\left(2^{\mathrm{r}}\right)$ contain "such savoured salt of wit" $\left(\mathbb{q} 2^{\mathrm{r}}\right)$; and, as for Troilus and Cressida, those who "will not praise it" $\left(\mathbb{q} \mathbf{2}^{\mathrm{v}}\right)$ are marked as needing serious prayers for "their wits' health" $\left(\mathbb{q} 2^{v}\right)$. The publisher's blurb is not alone in its playful semantics of healthy reading however.

In February 2011, I curated a small exhibition using some of the Cardiff University library's special collections. ${ }^{7}$ The exhibition, entitled Healthy Reading, put the unique preface to Shakespeare's Troilus and Cressida in the context of some of the culinary, literary, medical, and religious texts published between 1590 and 1690 (Figure 1). ${ }^{8}$

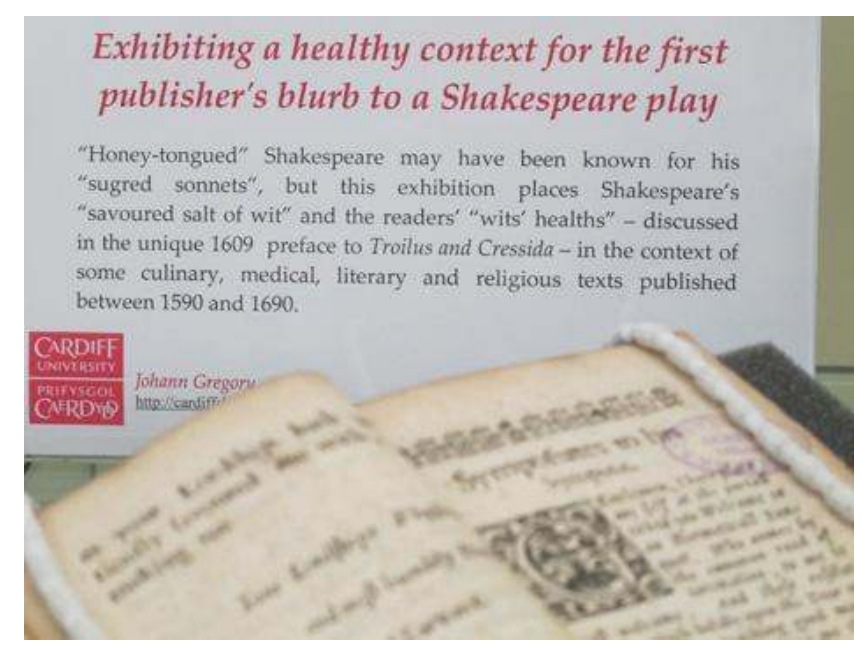

Figure 1 : Cardiff University library's “Healthy Reading” exhibition

\footnotetext{
6 Anon. "A never writer to an ever reader. Newes." in Troilus and Cressida (2nd state), London, Richard Bonian and Henry Walley, 1609 , sig. $\|_{2}{ }^{{ }}{ }_{-} \mathrm{v},\left(\mathbb{q}_{2}{ }^{\mathrm{r}}\right)$. For early modern books referenced in this paper, signatures or page numbers are given in parenthesis. Spelling has normally been silently modernised, except for book titles.

7 I am very grateful for the support I received from Alison Harvey (Assistant Archivist) and Peter Keelan (Head of Special Collections and Archives) in SCOLAR. Information about the exhibition can be accessed here:

http://www.cardiff.ac.uk/insrv/libraries/scolar/digital/images.html\#PGR1.

8 Author's photographs from the Healthy Reading 1590-1690 exhibition. All images (C) Cardiff University 2011; I am thankful for permission to publish these images in this paper.
} 
Although the exhibition was researched and curated under severe time constraints, the texts included demonstrated the early modern preoccupation with health, and how writers enjoyed using the discourse of food for different purposes. It is worth taking a quick look at some of these examples of healthy reading because they form a useful context to Shakespeare's play, often wittily associating food and expectation with the intellect, the body and pleasure.

Thomas Muffet's posthumously published Health's Improvement: or rules comprizing and discovering the nature, method, and manner of preparing all sorts of food used in this nation is just one example of the many dietary books published for health conscious consumers (Figure 2). ${ }^{9}$

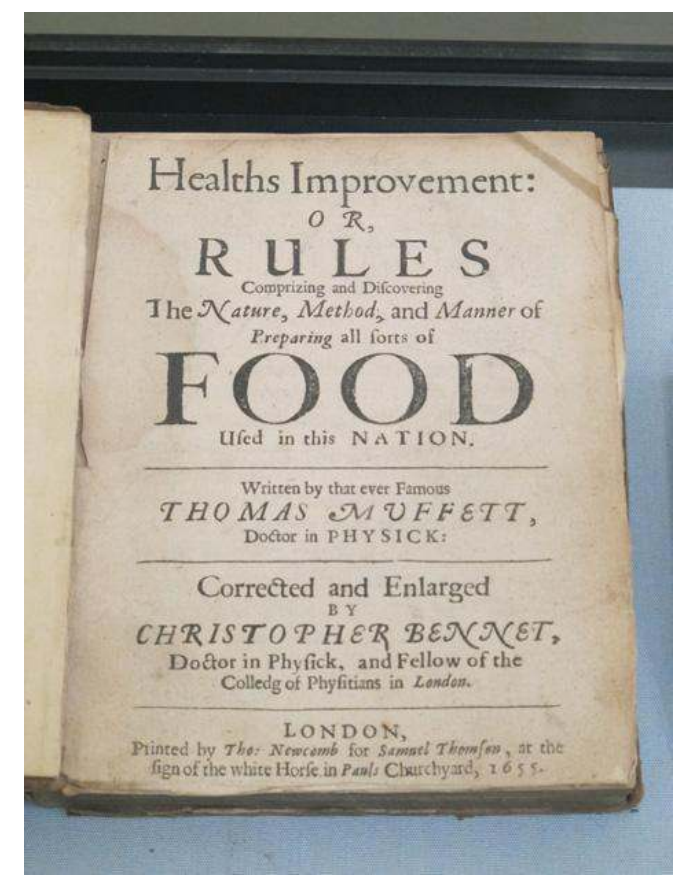

Figure 2 : Thomas Muffet's Health's Improvement

\footnotetext{
9 Thomas Muffett, Health's Improvement: or rules comprizing and discovering the nature, method, and manner of preparing all sorts of food used in this nation, London, Printed by Thomas Newcomb for Samuel Thomason, 1655 .
} 
The Breviarie of Health, Andrew Boorde's household medical book, was quite possibly "the first medical book, by a medical man, originally written and printed in the English language" (Figure 3). ${ }^{10}$

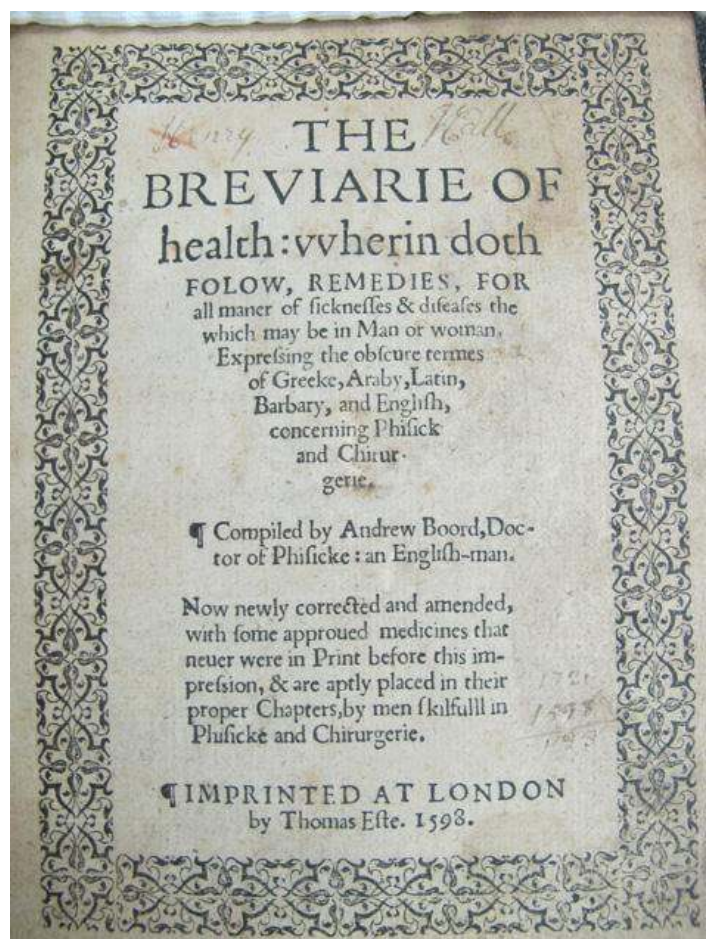

Figure 3 : Andrew Boorde's The Brevarie of Health

Besides the main concern with the human body, Boorde is also interested in the state of people's health in a more holistic and spiritual way. For example, his short chapter on the heart, "the principle member in man", contains a second heading: "To comfort the heart". Boorde writes:

${ }^{10}$ Douglas Guthrie, “The 'Breviary' and 'Dyetary' of Andrew Boorde (1490-1549), Physician, Priest and Traveller", The Proceedings of the Royal Society of Medicine 37 (1944), p. 506-509, 508. Andrew Boorde, The Brevarie of Health, London, Thomas Este, [1547] 1598. 
There is nothing that doth comfort the heart so much beside God, as honest mirth and good company. And wine moderately taken, doth letificate and doth comfort the heart, and good bread doth confirm and doth stabilise a man's heart. (p. 35)

Boorde's words pre-empt recent scientific research into laughter as something mentally and physically good for people. ${ }^{11}$ The reasoning seems close to Brillat-Savarin's approach in The Physiology of Taste, but it is also used as an early modern advertising technique - Troilus and Cressida, for example, being promised in the publisher's blurb to be good for your "wits' health".

The Assize of Bread was an official publication which sought to regulate the price of bread (Figure 4 ). ${ }^{12}$

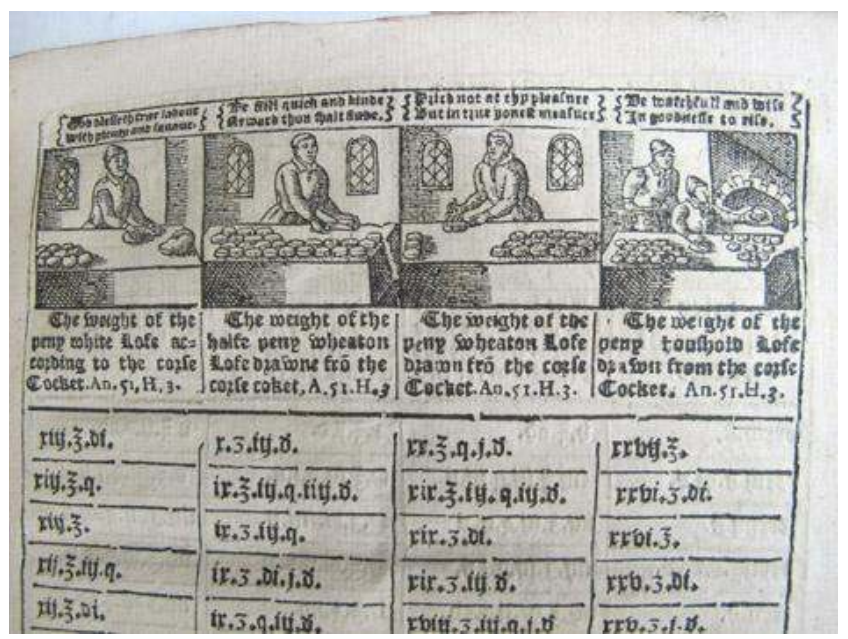

Figure 4 : The Assize of Bread

Nevertheless, this publication also included depictions of bakers, and above these images playful maxims such as: "Be watchful and wise in goodness to rise" $\left(\mathrm{C}_{3}{ }^{\mathrm{r}}\right)$. Someone, it seems, could not resist punning on the rising of bread and souls. The pocked book, Hygiasticon: or, the

\footnotetext{
${ }^{11}$ See, for a recent example, the BBC news item: "Laughing 'better than latest technology for leg ulcers"”:

http://www.bbc.co.uk/news/health-12699016 [Accessed 1oth March 2011]

12 John Powel, The Assize of Bread, London, Printed by Richard Bishop, [first issued 1600], 1636.
} 
right course of preserving life and health unto extream old age, written by the Flemish Jesuit Leonard Lessius, was ostensibly a serious piece of writing, but in this English edition it included a witty poetic prefix, "A Dialogue between a Glutton and Echo" (Figure 5). ${ }^{13}$

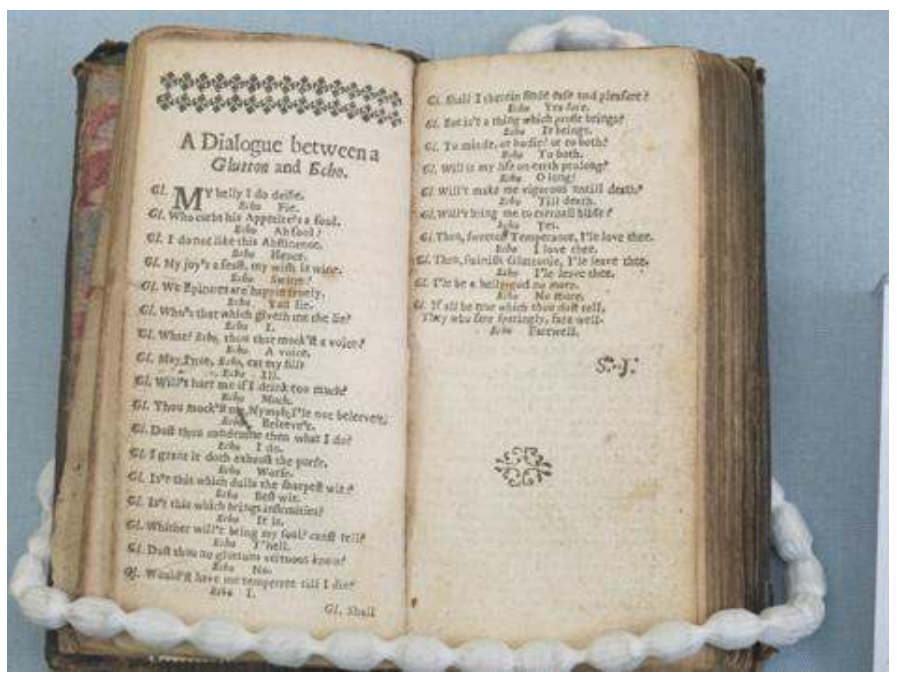

Figure 5 : Leonard Lessius' Hygiasticon

It begins:

Gl: "My belly I do deify".

$G l$ : Who curbs his appetite's a fool.

$$
\text { Echo: "Fie" }
$$

Echo: Ah fool!

Gl: I do not like this abstinence.

$G l$ : My joy's a feast, my wish is wine.

Echo: Hence

$G l$ : We Epicures are happy truly. Echo: Swine!

$G l$ : Who's that which giveth me the lie?

Echo: I.

\footnotetext{
13 Leonard Lessius, Hygiasticon: or, the right course of preserving life and health unto extream old age: The second Edition, Cambridge, [R. Daniel and T. Buck] the printers to the University of Cambridge, [Latin 1613], 1638.
} 
This exchange may have made the book more appetising and palatable, and certainly acted as healthy reading.

Like Brillat-Savarin, early modern physicians were also fusing professional discourses of digestion and health with entertainment. A Hermeticall Banquet: drest by a spagiricall cook for the better preservation of the microcosme constructs the reader as a diner and guest with the writer as a host (Figure 6). ${ }^{14}$

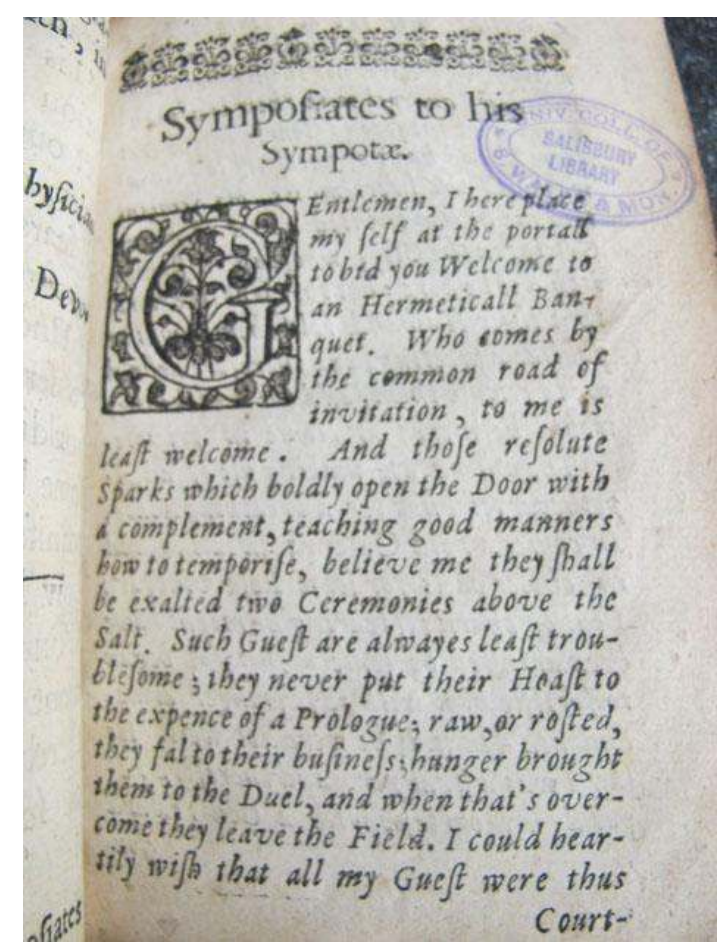

Figure 6 : A Hermeticall Banquet

It explores the body through four chapters, courses or journeys: "The First Course Stomaticall" (a journey to the stomach), "The Second Course Cephalicall" (a journey to the brain), "The Third Course

14 Attrib. Thomas Vaughan, A Hermeticall Banquet: drest by a spagiricall cook for the better preservation of the microcosme, London, Printed for Andrew Crooke, $1652,\left(\mathrm{~A}^{\mathrm{r}}{ }^{\mathrm{r}}\right.$ ). 
Hepaticall (a journey to the liver), and "The Fourth and Last Course Cardiacall" (a journey to the heart). However, the metaphor of food and the arts of the table are not confined to poetry and dietary books. Even Samuel Annesley's sermon was interestingly described as a "first dish" for the county feast (Figure 7). ${ }^{15}$

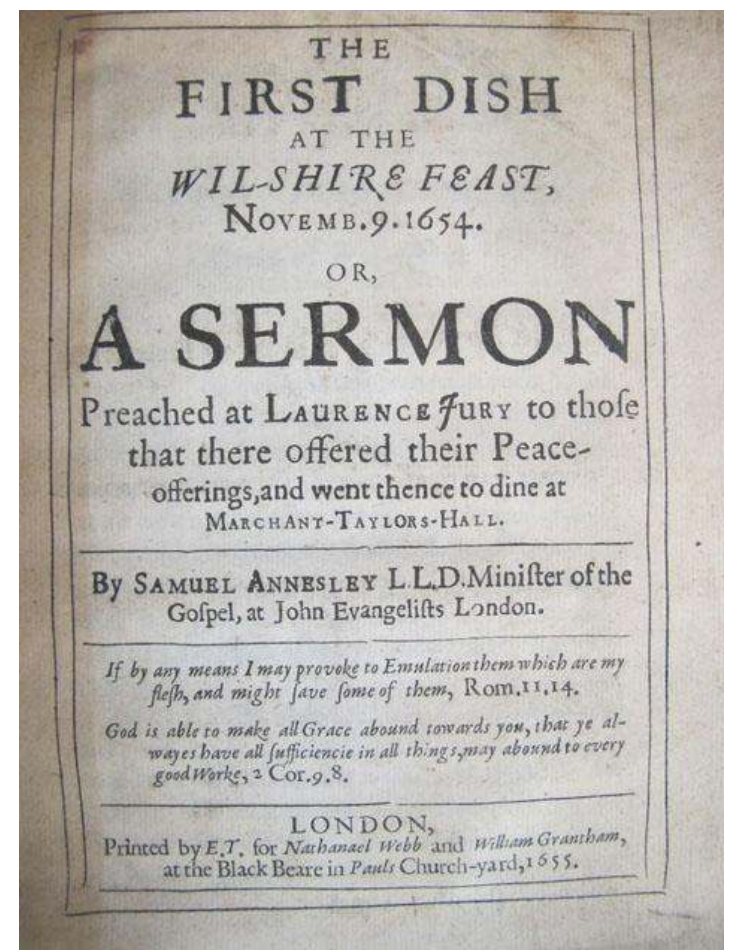

Figure 7 : Even Samuel Annesley's A Sermon

In the preface the clergyman cannot resist using gastronomic language: "I must confess there's a tang of indignation (in this crambe bis cocta [cabbage boiled twice]) this mushroom again set upon the table" $\left(\mathrm{A}^{\mathrm{r}}{ }^{\mathrm{r}}\right.$.

One of the most verbose uses of food imagery and gastronomic discourses involved the writings of the early modern travel writer

15 Samuel Annesley, The first dish at the Wil-shire feast, London, Nathanael Webb and William Grantham, 1655. 
Thomas Coryate. The subtitle to Coryats Crudities imagines his writing "Newly digested in the hungry aire of Odcombe in the Country of Somerset, and now dispersed to the nourishment of the travelling members of this Kingdome". ${ }^{16}$ John Taylor aka The Water Poet was literally and metaphorically larger than life; he also enjoyed travelling and seems to have found Coryate's use of gastronomic language and his volume's "Gogomagotical" size rather pompous, or at least vulnerable to ridicule, because he published a competitive retort to Coryate's foody travel writing entitled Laugh and Be Fat. ${ }^{17}$ Coryate, the more learned travel writer, arranged for the first editions of Taylor's 1612 publication to be burned although Laugh and Be Fat was reprinted in the Water Poet's 1630 collected works (Figure 8).

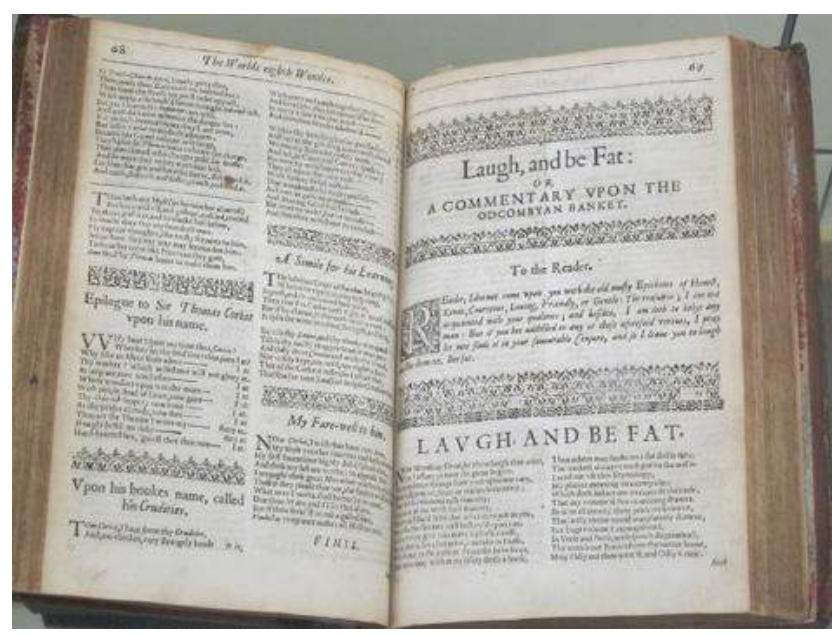

Figure 8 : John Taylor's Laugh and Be Fat

Together these publications suggest a pleasure in wittily associating reading, consuming and matters of taste, and a real concern with the relation between body and mind, and what they could

\footnotetext{
16 Thomas Coryate, Coryats Crudities, London, Printed by W[illiam] S[tansby for the author], 1611.

${ }^{17}$ John Taylor, Laugh and Be Fat in All the workes of John Taylor the water-poet, being sixty and three in number, collected into one volume by the author, London, James Boler, 1630 , p. $69-80$ (p. 69); this pagination is complicated by the fact that the book was printed in parts by four printers.
} 
take in. The witty titles and many of the paratexts also aim to be enticing. The early modern publications often utilise the title pages and paratexts as a menu or taster, like A Hermetical Banquet with its chapter titles, or rather dinner "courses". These books use the language of food and taste to set up expectations. Early modern titles often titillate, but this titillation of the intellect and the senses does not only work on the "ticklish reader" ${ }^{18}$ This gastronomic titillation can also be found in Shakespearean drama too, and especially in Shakespeare's Trojan play where expectations are visualised as a matter of taste.

\section{Le Plat Principal: visualising expectations as a matter of taste}

W.R. Elton explains that Shakespeare's Troilus and Cressida has "been estimated [to contain] twice as many images of food, cooking and related matters as in any other of its author's works". ${ }^{19}$ Elton does not provide a reference for this estimate, but he is probably referring to the work of Caroline Spurgeon. In her book Shakespeare's Imagery and what it tells us, Spurgeon uses a chart to produce "a pictorial statement of the dominating images in Hamlet and Troilus and Cressida". ${ }^{20}$ She focuses on two semantic fields: "Food, Drink, \& Cooking"; and, "Sickness, Disease, \& Medicine". As she describes, and her chart demonstrates, there are an "extraordinary number of food and cooking images in Troilus, which dwarfs all others of their kind throughout the plays, showing how much the poet's imagination ran on this subject in this play". ${ }^{21}$ Spurgeon explains that the "same two groups of images run though and dominate both plays, disease and food; in Hamlet the first is predominant, and in Troilus and Cressida the second". ${ }^{22}$ In the Trojan play, according to Spurgeon, "fourteen characters make use of

\footnotetext{
18 William Shakespeare, Troilus and Cressida, ed. Anthony B. Dawson Cambridge, CUP, 2003, (IV.v.61). All further references to Troilus and Cressida are to this edition; line numbers are given in parenthesis.

19 W.R. Elton, Shakespeare's 'Troilus and Cressida' and the Inns of Court, Aldershot, Ashgate, 2000, p. 135.

${ }^{20}$ Caroline Spurgeon, "Chart vII" in the appendix "Charts", in Shakespeare's Imagery and what it tells us, CUP, 1935, n. p. I am tremendously grateful to Charlie Harris for bringing Spurgeon's work to my attention.

${ }^{21}$ Spurgeon, op. cit., "Chart vII" in the appendix "Charts", n.p.

22 Ibid., p. 320.
} 
images of food, taste or cooking, and [...] there are no less than fortyfour such images in the play". ${ }^{23}$

It is perhaps in her analysis of the data for Troilus and Cressida that Spurgeon is disappointing after the promise of the second part of her book title "Shakespeare's Imagery and what it tells us". For Spurgeon, the use of food imagery apparently "tells us": that food ran through "the poet's imagination"; that this supports the evidence that Hamlet and Troilus and Cressida "were written near together"; and, perhaps worryingly, that they were written "at a time when the author was suffering from disillusionment, revulsion and perturbation of nature, such as we feel nowhere else with the same intensity". ${ }^{24}$ This is worrying because Spurgeon's comment that Shakespeare must have been disillusioned at the time of writing Hamlet and Troilus and Cressida - though it may be true - seems to limit the meaning of the text in a dangerous and over-simplistic way. Her reading is in danger of locating the significance of the food and disease imagery squarely in Shakespeare's temperament - the fact that at the age of "thirty-eight or thirty-nine" he developed a "sensitive digestion and a disgust of over eating" - rather than in the temperament of his characters, or within Shakespeare's artistry, intertexts and contexts. ${ }^{25}$ The abstract for this paper promised an attempt to "discover whether the play leaves us with 'fragments, scraps, the bits, and greasy relics' of past literature, or if Shakespeare was cooking up something else". And so this paper hopes to at least provide some suggestions to the question of why there are quite so many references to food and culinary activities in this play.

A paper on Troilus and Cressida at a conference devoted to the arts of the table could be in danger of deconstructing the operations of cordiality, hospitality and, perhaps worse, put everybody off their food. Nevertheless, it seems expected that this paper should at least give a taste of the cooking and distaste at work in Troilus and Cressida. Please hold on to your stomachs. Spurgeon has usefully given these gastronomic images from the play on a plate. They include images of

Seething, stewing, mincing, baking, larding, stuffing, broiling, basting, brewing, frying, kneading, boiling and stirring the ingredients for a pudding. [As Spurgeon notes, the kinds of cooking are described]

\footnotetext{
23 Ibid., p. 323

24 Ibid., p. 320

25 Ibid., p. 121.
} 
sometimes at considerable length, as in the metaphors on grinding the wheat, bolting, leavening, kneading, making the cake, heating the oven, baking and cooling, carried on with expert knowledge by Pandarus and complete understanding by Troilus in the opening of the play.

A "crusty batch" (of bread), cheese served for a digestive, or mouseeaten and dry, an addled egg, a pie, porridge after meat, a dish of fool (stewed fruit crushed with cream), a fusty nut, a hard sailor's biscuit, fair fruit rotting untasted in an unwholesome dish, and greasy remnants of food, are, in addition, all pressed into service; as are also hunger, appetite, ravenous eating, digestion, fasting, feeding, tasting, drinking up the lees and dregs of wine, tossing off a toast, sauce, flavouring, salt, sweet and sour. ${ }^{26}$

All these excessive references to food and cooking might be enough to upset the strongest of stomachs, but what makes this worse is that the play soon starts to juxtapose the images of cooking and food with that of disease and decay. Troilus and Cressida includes references to "ulcer[s]" (I.i.49), "gash[es]" (I.i.58), "bleed[ing]" (I.i.106), "jaundice" (I.iii.2), "choking” (I.iii.27), being "sick” (I.iii.133), "fever" (I.iii.134) "withered brawns" (I.iii.298), "boils" (II.i.4), "botchy cores" (II.i.5), "a loathsomest scab", "mouldy" (II.i.95) wits, "infectious" (II.ii.59) affectations, "blood [...] madly hot" (II.ii.115-6), "brain-sick raptures" (II.ii.122), "hot passion of distempered blood" (II.ii.169), "Neopolitan bone-ache”, (II.iii.15), “corpse[s]” (II.iii.27), "lazars" (II.iii.28), "serpigo" (II.iii.66), and finally a greasy and gelatinous Achilles as a proud lord "that bastes his arrogance with his own seam" (II.iii.169), with Ulysses concern that they should not "enlard his fat-already pride" (II.iii.179). All these discomforting references are taken just from the first two acts of the play, but it is perhaps best not to continue with these "fragments, scraps, the bits, and greasy relics" (v.ii.159) in Patroclus' words: "for your health and your digestion sake" (II.iii.99).

The point that needs to be to emphasised is that the representation of food in Shakespeare's theatre is a risky business because it can so easily lead to excess, sickness and, as Patricia Parker has noticed, bloating. ${ }^{27}$ This risk of an audience being upset by food is a key issue for Michael Dobson in his essay published in the special Stage and Banquet 2009 volume of the Shakespeare Jahrbuch.

26 Ibid., p. 323.

${ }^{27}$ See her chapter, "Dilation and Inflation: All's Well That Ends Well, Troilus and Cressida, and Shakespearean Increase" in Patricia Parker, Shakespeare from the Margins: Language, Culture, Context, Chicago, Chicago University Press, 1996, p. 185-228. 
Dobson notes that "[a]lthough in conventional Western drama food usually functions primarily as a social signifier kept within the fictitious world of the play, food, and, even the discussion of food, can trigger actual physical responses of its own in audiences, some of them intrusively negative". ${ }^{28}$ This notion that the play can generate a "physical response" is something that might help us to understand the frequency of food and culinary images in the play. For a long time now, critics have noted how Troilus and Cressida seems to be an experimental play; one thing that Shakespeare's play really seems to be experimenting with, however, is a different kind of poetics that triggers audience expectations and then aims to produce mental and indeed physical responses. ${ }^{29}$

This notion of risky anticipation is taken up in the very opening of the play when the prologue says that

Now expectation, tickling skittish spirits

On one and other side, Trojan and Greek,

Sets all on hazard.

(Pro. 20-22)

And that "our play" begins:

in the middle, starting thence away,

To what may be digested in a play.

Like, or find fault, do as your pleasures are,

Now good or bad, 'tis but the chance of war.

(Pro. 28-31)

Elsewhere critics have argued that this "war" could refer to the strife of competing poets and theatres as well as the Trojan War..$^{30}$ But this "war" could also refer to a battle of the senses in relation to an audience's expectation and their pleasures.

This way of viewing something through the analogy of a warrior's view of war is made explicit in the opening scene with Troilus. The play proper begins:

\footnotetext{
28 Michael Dobson, “'His Banquet is Prepared': Onstage Food and the Permeability of Time in Shakespearean Performance", Shakespeare Jahrbuch: Bühne und Bankett 64, 2009, 6273 , p. 62.

${ }^{29}$ I am using the expression "poetics" simply as a term to describe a series of semantic fields or discourses at work in the text, namely of expectation, gastronomy and taste.

$3^{0}$ See James P. Bednarz, Shakespeare and the Poets' War, New York, Columbia University Press, 2001 and Johann Gregory, "The 'author's drift' in Shakespeare's Troilus and Cressida: A Poetics of Reflection" in Medieval and Early Modern Authorship SPELL: Swiss Papers in English Language and Literature 25, ed. Lukas Erne and Guillemette Bolens, Tübingen, Narr, forthcoming 2011.
} 
Call here my varlet - I'll unarm again.

Why should I war without the walls of Troy

That find such cruel battle here within?

This cruel battle within, it transpires, is due to his anticipation of a time when he can "come to Cressid" (I.i.89). Using the metaphor of baking, Pandarus says "he that will have a cake out of the wheat must tarry the grinding" (I.i.14-15), and then, "tarry the bolting" (I.i.17), "tarry the leavening" (I.i.19), the "kneading, the making of the cake, the heating of the oven and the baking" (I.i.21-23). Pandarus is obviously confusing the anticipation with the sexual act itself. A hangover from Pandarus' extended metaphor today is perhaps the expression "to have a bun in the oven" - to be pregnant. What most scholars have not noted, in fact, is that just as most readers of a Trojan War story know that the walls will fall, so, in this play, the language of food is linked with anticipatory language, or a language of expectation.

So, rather than simply pointing out that there are many references to food in this play, it can be suggested that, firstly, the language of cooking and food is part of a poetics that visualises characters' expectations. An obvious example occurs when Pandarus tells Troilus to "Wait here i'th'orchard, I'll bring her [Cressida] straight” (III.ii.14). At this moment, Troilus links expectation and matters of taste in a rare soliloquy:

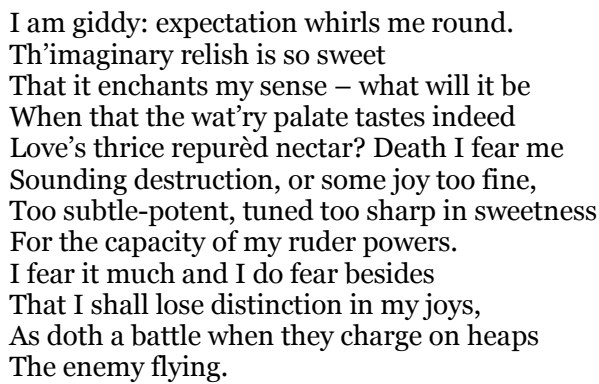

Troilus visualises his imagined experience of Cressida as "a thrice repurèd nectar" which is interesting because it suggests refinement both metaphorically and in a culinary sense. Cressida is described as something to be appreciated by one with a refined taste; but also Cressida, as a honey, will have been refined - one might say reprocessed - just as Shakespeare has to re-present her. Troilus then 
goes on bizarrely to suggest that his inability to appreciate the distinction of this joy could be like the way in which an army charge on an enemy indiscriminately.

To move on to the second suggestion regarding the visualisation of expectation in the play, critics have noticed the shared semantic fields of food and disease in both the so-called love plot and the war plot, but in a witty way the anticipation of love and war is linked, too, with the experience of a theatre-goer or reader. This line of argument is still in its nascent stage, but the intensely metatheatrical quality of this play lends itself to such reasoning. ${ }^{31}$ To take an example from $\mathrm{Dr}$ Faustus, alluded to in Troilus and Cressida, when Faustus watches Mephistopheles conjure Helen of Troy, Faustus exclaims "was this the face that launched a thousand ships / And burnt the topless towers of Ilium?". ${ }^{2}$ Faustus may be asking "was Helen the cause of the Trojan War?", but in a kind of theatrical joke, for the audience, he may simultaneously be asking "is this face really anything like Helen's?". The implied experience of the character is in some way linked to that of the audience. This joining of a character's experience with that of the audience is one of Shakespeare's trade-mark theatrical tricks to make the audience identify with a character. In Troilus and Cressida, however, an audience is not necessarily invited to identify with the characters - in fact perhaps quite the reverse - but the audience may be taken in by the sense of expectation, by the language describing the character's hopes and disappointments, desires and frustrations. Nevertheless, the expectations of audiences are not simply their desire for love or war, but their desire for pleasure, as suggested by the play's prologue:

Like, or find fault, do as your pleasures are, Now good or bad, 'tis but the chance of war.

(Pro. 30-31)

In this drama Shakespeare seems to deliberately play with audience expectations, expectations of epic grandeur from Homer, chivalric love from Chaucer, refined sentiments and wise sayings for

\footnotetext{
${ }^{31}$ The (distressed) link between the expectations of the characters and the expectations of an audience is in fact the major facet of my $\mathrm{PhD}$ dissertation on Troilus and Cressida.

$3^{2}$ Christopher Marlowe, Doctor Faustus, in Six Renaissance Tragedies, ed. Colin Gobson, Basingstoke, Macmillan, p. 131, (I.v.90-91). In Troilus and Cressida, Helen is commodified when Troilus says: "Why, she is a pearl / Whose price hath launched above a thousand ships / And turned crowned kings to merchants" (II.ii.81-83)
} 
the audience's common place books. 33 For example, Paris' scene with Helen is perhaps the rotten core of Shakespeare's play. Paris says of Pandarus to his "love" Helen:

He eats nothing but doves, love, and that breeds hot blood, and hot blood begets hot thoughts, and hot thoughts beget hot deeds, and hot deeds is love.

What the play delivers can in fact be dis-easing - as Pandarus makes clear in the play's final line when he promises to "bequeath [his] diseases" (V.xi.54) to the audience. After Twelfth Night's promise to "strive to please you every day" (v.i.407), audiences may not have expected this digestive Trojan rollercoaster - a play where "honour [...] and what else dear" is "consumed / In hot digestion of this cormorant war" (II.ii.6). Rather than fleshed out characters and gripping plots, Shakespeare - for a change - experiments with the physical and witty humours of a kind of satire of his contemporaries Ben Jonson and John Marston, but sends up and inflates to bursting point their theatre of taste - no wonder Troilus and Cressida has been thought by critics to be the Parnassus Plays' "purge" that Ben Jonson was made to take after writing Poetaster. 34

Unlike many of Shakespeare's other plays, food may not be physically manifest in Shakespeare's Trojan play - there is nothing in the dialogue or stage directions that specify that a banquet, for example, takes place on stage - but rather, in a witty (perhaps biblical) conceit, words become a kind of food that is taken in by the mind. "Lo, lo, lo, lo", says Thersites sarcastically of the "beef-witted" (II.ii.9) Ajax, "what modicums of wit he utters" (II.i.61). The Oxford English Dictionary informs us that in early modern English "modicum", meaning a tiny amount, could be used as "a slang term for: something eaten in order to stimulate thirst". Thersites' sarcastic comment plays on this sense that wit could be nutritious and enticing. It is perhaps not

\footnotetext{
33 For the audience's common place books, and other books in the theatre see, for example, Tiffany Stern "Watching as Reading: The Audience and Written Text in Shakespeare's Playhouse" in How To Do Things With Shakespeare: New Approaches, New Essays, ed. Laurie Maguire, Oxford, Blackwell, 2008, p. 136-59.

34 For Troilus and Cressida as a response to Poetaster, and as the Parnassus Plays' "purge" see Bednarz, Shakespeare and the Poets' War and Gregory, "The 'author's drift"”. The classic reading of Troilus and Cressida in relation to the satire of Shakespeare's contemporaries is Oscar James Campbell, Comicall Satyre and Shakespeare's 'Troilus and Cressida', San Marino, Henry E. Huntington Library and Art Gallery, 1938.
} 
surprising that Troilus and Cressida is in the top four Shakespeare plays for the highest frequency of the word "wit", with As You Like It, Much Ado and Love's Labours Lost. 35

That Shakespeare's play was experienced by early modern audiences as something that played wittily with the senses is suggested by the quarto epistle writer to the play. As Zachary Lesser points out:

[...] what has not been stressed is that the preface is also a reading of the play. Bonian and Walley are not merely the play's publishers: when they reconsidered their understanding of the play and inserted the preface, they became the earliest literary critics to publish on Shakespeare's Troilus and Cressida. ${ }^{36}$

So, the publishers had taken the way that the play visualised expectations as a matter of taste in order to make readers hungry to buy the quarto publication: the play contains "such savoured salt of wit" ( $\left(2^{\mathrm{r}}\right)$; it is a "new" ( $\left(2^{\mathrm{r}}\right)$ fresh play, "never staled by the stage, never clapper-clawed with the palms of the vulgar" ( $\left(2^{\mathrm{r}}\right)$; but, most of all, it is good for your "wits' health" $\left(\Upsilon^{\mathrm{v}}{ }^{\mathrm{v}}\right)$. The epistle writer taps into the great expectations for a play written by Shakespeare, entitled Troilus and Cressida and set during the Trojan War. All the same, just as Cressida, for Troilus, turned out to be "a stainèd name" (v.ii.178), so Shakespeare's play raises and then challenges expectations; images of food enrich the anticipatory language of the play, but they also work as a cultural marker of expectations.

\section{Le Dessert: "Shack-spear, Butler"}

In Shakespeare's sonnet 141, the poetic voice says "But my five wits nor my five senses can / Dissuade one foolish heart from serving thee".37 The five senses - sometimes called the outer wits in medieval writing are well known, but the five (inner) wits have been lost, except in expressions such as to be "out of your wits", to have "lost your wits" or to be "at your wits' end". The five wits included common sense (which

\footnotetext{
35 This statistic is based on a search of Ben and David Crystal's website: http://www.shakespeareswords.com [Accessed 23rd February 2011].

${ }^{36}$ Zachary Lesser, Renaissance Drama and the Politics of Publication: Readings in the English Book Trade, Cambridge, CUP, 2004, p. 2.

37 William Shakespeare, Sonnets in The Norton Shakespeare, ed. Stephen Greenblatt, Walter Cohen, Jean E. Howard and Katharine Eisaman Maus, New York, W.W. Norton and Company, 1997, p. 1923-1976, (l. 9-10, p. 1971).
} 
was in charge of translating sensory perception from the five senses), imagination, fantasy, estimation and memory. ${ }^{38}$

In the 1652 publication of $A$ Hermetical Banquet, Sir Isacke Wake's physician produced an elaborate banquet / journey into the human body and mind that plays again on poetry and matters of taste (Figure 6 above). Interspersed with recipes, the second chapter, "The Second Course Cephalicall", takes his reader-guests right into the mind. And there, in the halls of the third wit, fantasy or Phantasia, one finds her minion, Poeta:

to whom she resignes the whole government of her Family. She makes Hay whilst the Sun shines; and prefers all her poor kindred to severall Places in the Court.

Ovid she makes Major-domo. Homer because a merry Greek Master of the Wine-Cellars. Aretine (for his skill in Postures) growing old, is made Pander. Shack-spear, Butler. Ben Iohnson, Clark of the Kitchin, Fenner his Turn-spit, And Taylor his Scullion. (p. 35)

This forgotten reference to the bard is interesting because it suggests that it is not just a modern idea to see Shakespeare in culinary terms. 39 The wit Shakespeare displays in his Trojan play was not simply a clever wit, or a shrewd wit, it was the ability to play with language to engage the five senses that are "the windows, through the which [the soul] views the light of knowledge", in the words of Sir John Davies from the Middle Temple Inn in his 1599 publication Nosce Teipsum.40 Shakespeare must have known that these images of food would play havoc when they were served up to an audience's common sense and were sent on through the wit of imagination to "Phantasie, near handmaid to the mind" (p. 46) in Davies's phrase. So, although the epistle writer to Troilus and Cressida was in the business of selling his book, he was perhaps right to say "Amongst all [his comedies] there is

\footnotetext{
$3^{8}$ For more on the five wits see, for example, Stephen Hawes, The historie of graunde Amoure and la bell Pucel, called the Pastime of plesure co[n]teining the knowledge of the seue[n] sciences, [and] the course of mans life in this worlde. Iuuented [sic] by Stephen Hawes, grome of kyng Henry the seuenth his chamber, London, John Wayland, 1554, especially "Capit. xxiiii" (N.2. ${ }^{\mathrm{H}}$-N.3. ${ }^{\mathrm{V}}$ ).

39 There are only a handful of references made by critics to this allusion; the most recent that I have found being in Peggy Muñoz Simmonds, "Love is a spirit all compact of fire': Alchemical coniunctio in Venus and Adonis", Glasgow Emblem Studies 3, 1998, p. 133-156. $4^{\circ} \mathrm{Sir}$ John Davies, Nosce teipsum this oracle expounded in two elegies, 1. Of humane knowledge, 2. Of the soule of man, and the immortalitie thereof, London, John Standish, 1599 , p. 41.
} 
none more witty than this. And" to continue the publisher's words "had I time I would comment [further] upon it”.

Johann GREGORY

Cardiff University 